\title{
Okul Yöneticilerinin Duygusal ve Sosyal Zekâları ile Liderlik Stilleri Arasındaki ilișkinin İncelenmesi*
}

\author{
Baran Barış YILDIZ', Tevfik Sertaç ÇELIKÇEKEN², Mesut GÜLPER³
}

\begin{abstract}
Öz: Bu araştırmanın amacı, okul yöneticilerinin duygusal zekâ ve sosyal zekâ yeteneklerinin cinsiyet ve yaş değişkenleri açısından anlamlı düzeyde farklılaşıp farklılaşmadığını, okul yöneticilerinin duygusal zekâ ve sosyal zekâ yeteneklerinin liderlik stillerini anlamlı düzeyde yordayıp yordamadığını belirlemektir. Araştırmanın verilerinin toplanmasında WLEIS, Tromso Sosyal Zekâ Ölçeği, Çok Faktörlü Liderlik Ölçeği ve Kişisel Bilgi Formu kullanılmıştır. Araştırmanın örneklemini; 2019-2020 eğitim-öğretim yılı İstanbul ili Avcılar, Beyoğlu, Çatalca, Esenyurt ve Güngören İlçelerinde görev yapan 67 kadın ve 210 erkek olmak üzere toplam 277 eğitim yöneticisi oluşturmaktadır. Verilerin istatiksel analizinde bağımsız örneklemler için T testi, tek yönlü varyans analizi, Tukey testi ve çok değişkenli doğrusal regresyon analizi kullanılmıştır. Analiz sonuçlarına göre, eğitim yöneticilerinin duygusal zekâ yeteneklerinin bütün olarak dönüşümcü liderlik stili ve serbestlik tanıyan liderlik stili puanlarını yordadığı, sürdürümcü liderlik stili puanlarını ise yordamadığı tespit edilmiştir. Duygusal zekâ yetenekleri dönüşümcü liderlik stilindeki toplam varyansın $\% 36,7^{\prime}$ sini ve serbestlik tanıyan liderlik stilindeki toplam varyansın \%26,2'sini açıklamaktadır. Yine eğitim yöneticilerinin sosyal zekâ yeteneklerinin bütün olarak dönüşümcü liderlik stili, sürdürümcü liderlik stili ve serbestlik tanıyan liderlik stili puanlarını yordadığı tespit edilmiştir. Sosyal zekâ yetenekleri dönüşümcü liderlik stilindeki toplam varyansın \%38,7'sini, sürdürümcü liderlik stilindeki toplam varyansın $\% 15,6^{\prime}$ sını ve serbestlik tanıyan liderlik stilindeki toplam varyansın \%34,3'ünü açılamaktadır.
\end{abstract}

Anahtar Sözcükler: Duygusal zekâ, Sosyal zekâ, Dönüşümcü liderlik, Sürdürümcü liderlik, Serbestlik tanıyan liderlik

\section{Examining the Relationship Between Emotional Intelligence and Social Intelligence of School Principals and Their Leadership Styles}

\begin{abstract}
The aim of this research is to determine whether the emotional intelligence and social intelligence skills of school principals show a significant difference in terms of their gender and age, and to determine whether the emotional intelligence and social intelligence skills of school principals predict their leadership styles. The WLEIS (Wong \& Law Emotional Intelligence Scale), the Tromso Social Intelligence Scale, the Multifactor Leadership Questionnaire and a Personal Information Form were used to collect the data. The research sample consists of 277 school principals, 67 women and 210 men, from Avcllar, Beyoğlu, Çatalca, Esenyurt and Güngören districts of İstanbul. Independent T-Test, One-way Analysis of Variance, Tukey test and Multiple Linear Regression Analysis were used in the statistical data analysis. According to the results of the analysis, it was determined that the emotional intelligence skills of the principals predicted the transformational and laissezfaire leadership styles scores as a whole but did not predict the transactional leadership style scores. Emotional intelligence skills explain $36.7 \%$ of the total variance in the transformational leadership style and $26.2 \%$ of the total variance in the laissezfaire leadership style. It was determined that the social intelligence skills of the principals predicted the scores of the transformational leadership style, transactional leadership style and laissez-faire leadership style as a whole. Social intelligence skills explain $38.7 \%$ of the total variance in the transformational leadership style, $15.6 \%$ of the total variance in transactional leadership style, and $34.3 \%$ of the total variance in laissez-faire leadership style.
\end{abstract}

Keywords: Emotional intelligence, Social intelligence, Transformational leadership, Transactional leadership, Laissez-faire leadership

\footnotetext{
* Bu Çalışma, 30.10.2020- 01.11.2020 tarihlerinde Biruni Üniversitesi'nde düzenlenen 6. Uluslararası TURKCESS Eğitim ve Sosyal Bilimler Kongresi'nde Sözel Bildiri olarak sunulmuştur.

${ }^{1}$ Millî Eğitim Bakanlığı, İstanbul, Türkiye, e-posta: bbaris yildiz@windowslive.com, ORCID: https://orcid.org/0000-0003-1247-3158

2 Milli Eğitim Bakanlığı, İstanbul, Türkiye, e-posta: sertaccelikceken@gmail.com, ORCID: https://orcid.org/0000-0002-0733-1510

${ }_{3}^{3}$ Millı̂ Eğitim Bakanlığı, İstanbul, Türkiye, e-posta: mesutgulper@hotmail.com, ORCID: https://orcid.org/0000-0003-3352-6212
} 
Son yıllarda eğitim örgütlerinde liderlik stilleri ve etkili liderlik kavramları gittikçe önemini arttıran kavramlar olarak öne çıkmaktadır. Özellikle etkili liderlik, içinde bulunduğumuz yüzyıl gibi değişim dönemlerinde belki de her zamankinden daha önemlidir (Türker, 2008). Rossow (1990) etkili okulların, etkili liderler tarafından yönetildiğini vurgular (Tanriöğen, 1997). Aynı şekilde Balcı'da (2010) örgütsel etkisizliğin çok büyük oranda insan hatasından kaynaklandığını bunun \%95'inin de yönetici kaynaklı olduğunu belirtmektedir. Okullarda atanmış lider konumunda olan eğitim yöneticilerinin öğretmenlere, öğrencilere ve okulla ilgili diğer çalışanlara etkili liderlik etmesinde belki de en önemli değişkenin kullandıkları liderlik stilleri olduğu söylenebilir.

Literatürde liderliği ve liderlik stillerini açıklamada çeşitli teoriler bulunmakla beraber bu çalışmada Bass'ın (1985) "Çok Faktörlü Liderlik Teorisi" temel alınmıştır. Bu teoride liderlik, dönüşümcü, sürdürümcü ve serbestlik tanıyan liderlik stillerinin bir bileşeninden oluşmaktadır (Baloğlu ve diğerleri, 2009). Leithwood (1992) tarafından eğitim örgütleri için de kullanılmaya başlanmıştır. Bass'a (1998) göre dönüşümcü liderlik, insanların zihninde ideal olarak tanımladıkları liderin davranış tipini yansıtmaktadır ve dönüşümcü liderliğin bir durumsal liderlik teorisi olduğunu ifade etmektedir. Tichy ve Devanna (1986) böyle liderleri karar verirken risk almaya istekli ve kendisini bir değişim ajanı olarak var eden kişiler olarak tanımlamıştır. İlk defa Downton (1973) tarafından kullanılan sürdürümcü liderlik stilini ise Burns (1978) dönüşümcü liderliğin zıddı olarak açıklamış ve bir bireyin ne kadar sürdürümcü ise o kadar az dönüşümcü olacağını ifade etmiştir. Buna karışın Bass (1998) çok faktörlü liderlik teorisinde, bireyin hem dönüşümcü hem de sürdürümcü davranışlara sahip olabileceğini ifade etmekte ve liderin bu iki davranışı sergilemesini durumsallıkla açıklamaktadır. Ona göre güçlü liderler hem dönüşümcü hem de sürdürümcü olabilen kişilerdir. Sürdürümcü davranışı ise çalışanların hizmetleri ile liderin elinde bulundurduğu ödüllerin değişimini sağlayan bir takas sistemi üzerinde temellendirmekte ve örgütsel hedeflerin gerçekleştirilmesi ve çalışanların iş başarımının bu yolla sağlanabileceğini ifade etmektedir. Serbestlik tanıyan liderlik ise adından anlaşılacağ gibi liderin işe karışmadığı, işten sakındığı liderlik stilini ifade etmektedir. Bass ve Avolio (2000) sorunları sürekli erteleyen, karar vermekten kaçınan ve ihtiyaç duyulduğunda ortada olmayan lider davranışını serbestlik tanıyan lider olarak tanımlamaktadır.

Eğitim yöneticilerinin etkili liderlik etmesinde önemli bir diğer değişken de 21.yüzyılın başından itibaren liderlik alanında gittikçe önemini arttıran duygusal zekâ kavramıdır (Hayashi ve Ewert, 2006; Mandell ve Pherwani, 2003; Mills, 2009; Palmer ve diğerleri, 2001; Rahman ve diğerleri, 2012; Sayeed ve Shanker, 2009). Bu durumun en önemli nedenlerinden biri, liderliğin ve onun özünü oluşturan etkileme sürecinin merkezinde duyguların yer almasının anlaşılmasıdır (Karadavut ve Çetin, 2017). Goleman'a (2000) göre bir liderin başarıyı yakalayabilmesinin anahtarı duygusal zekâ yeteneklerine sahip olmasıdır (Kutlualp ve Erol, 2007). Salovey ve Mayer (1990)'e göre duygusal zekâ; kişinin kendisinin ve diğerlerinin duygularını değerlendirme, ayrım yapabilme ve buradan elde ettiği bilgileri düşünce ve davranışlarında kullanabilme yeteneği olarak tanımlanmaktadır. Duygular her insanda vardır, ancak yalnızca duygulara sahip olmak yeterli değildir. Duygusal zekâ; diğerlerinin ve kendimizin duygularını tanıma ve değerlendirmenin dışında duyguların enerjisini ve duygulara ilişkin bilgilerimizi günlük hayatımıza ve iş hayatımıza etkili bir şekilde yansıtarak onlara uygun tepkiler vermemizi sağlar (Yeşilyaprak, 2001). Bu nedenle duygusal zekânın geliştirilmesinin oldukça önemli olduğu söylenebilir. Çünkü özel hayatta olduğu gibi iş yaşamında da başarının belirlenmesinde önemli rol oynamaktadır (Ruderman vd. 2001, aktaran Kutlualp ve Erol, 2007).

Goleman'a (2002) göre grubun duygusal rehberi liderdir. Liderin görevi, olumsuz duyguların oluşturduğu havayı ortadan kaldırarak, kollektif duygulara olumlu yön vermektir. Lider, örgütün duygusal ikliminin oluşumuna da duygulara hitap ederek, kendisine bağlı olanların ruh halini etkileyip katkı sağlar. Bu sebepten dolayı da liderlerin duygusal zekâları yüksek olmalıdır (Brockert ve Braun, 2000, aktaran Türker, 2008). Çünkü, liderin bir diğer görevi de çalışanların bilgi ve becerilerini kullanmak için motive etmek, performanslarını arttırmak ve örgütte olumlu çevre yaratmaktır (Kapıkıran, 2004). Nitekim araştırmalar da liderlerin duygusal zekâsının, çalışanların performans ve örgüt verimliliği üzerinde olumlu etkisinin olduğunu göstermektedir (Connelly ve Ruark, 2010; Gürbüz ve Yüksel, 2008; Wong ve Law, 2002).

Örgütlerde somut sorunları çözmek daha kolaydır. Soyut ve mekanik zekâ ile akılcı yöntemler 
bulunabilir. Ancak, insan varlığının olduğu yerde duygular da sürece katılmaktadır (Şenturan, 2014). Bu duygular olumlu durumları ortaya çıkarabileceği gibi çatışmalara da sebep olabilir. Çatışma yaşayan bireylerin günlük hayatlarında ya da iş hayatlarında stres düzeylerinin yükselmesi ile birlikte anlık duygu patlamaları, öfke sorunları ortaya çıkabilmektedir. Bu durumda bireyin akademik zekâsı ve duygusal zekâsı yetersiz kalmakta ve farklı bir yetenek devreye girerek sorunun çözümünü sağlaması gerekmektedir. İşte bu durumda devreye girerek sorunun çözümünde etkin rol oynayan zekâ, sosyal zekâdır (Özülke, 2015, aktaran Şahin ve Şahin, 2017). Nitekim araştırmalar da sosyal zekâsı yüksek bireylerin çatışma çözmede başarılı olduklarını göstermektedir (Kanbur, 2015; Selçuk ve diğerleri, 2002; Şahin ve Şahin, 2017). Sosyal zekâ, insanlar ile başarılı bir şekilde iletişim kurabilmek, onları anlayabilmek için gerekli becerilerin bir birleşimidir. Diğerleri ile iyi geçinebilme ve iş birliği yapmalarını sağlayabilme yeteneğidir (Albert, 2006). Thorndike'a göre ise sosyal zekâ, insanları anlayabilme ve idare edebilme yeteneğidir (Goleman, 2014). Sosyal zekâ konusunda çalışan pek çok araştırmacı sosyal zekâ kavramını akademik zekâ, duygusal zekâ veya dilsel yetenek gibi pek çok benzer kavramdan ayırmakta güçlük çekmiş ve sosyal zekâ kavramının gerçekten ayrı ve kullanışlı bir kavram olup olmadığını sorgulamıştır (Björkqvist ve diğerleri, 2000). Bu kavramsal kargaşa içerisinde duygusal zekâ ve sosyal zekâ ayrımı şu şekilde açıklanabilir; Duygusal zekâ duyguların akıllıca kullanımı olup, istediğimiz sonuçlara ulaşmak için duygularımızı istediğimiz yönde kullanma yeteneğidir (Weisinger, 1998; Mumcuoğlu, 2002). Duygularımızı tanımak, denetlemek ve yönetmek gerekir. Sosyal zekâ ise; insanlarla birlikte çalışabilme, çok farklı karakterlere sahip insanlarla kolaylıkla iletişim kurabilme, insanları yönetebilme, onlarla uyumlu çalışabilme ve insanları ikna edebilme becerisidir (Özcan, 2018). Sosyal zekâ, diğer insanlarla birlikte olma, onları anlama, kendini ifade edebilme ve ilişki sürdürme becerilerini içerir. Nitekim literatürde duygusal zekâ ve kültürel zekâ konularının dişında bir görüşle çalışanların birbirleriyle olan etkileşim becerilerini sosyal zekâ olmadan açıklayabilmenin mümkün olmadığı bildirilmiştir (Boyatsiz, 2009; Genc ve Gulertekin Genc, 2018). Çünkü sosyal zekâ bireyin kendisini ve çevresindeki sosyal ilişkileri anlayabilmesinde kilit rol oynamaktadır (Lathesh ve Vidya, 2018). Liderlerin de bir çalışan olmaları ve örgüt içerisindeki sosyal ilişki ağında kilit bir rolü olduğu düşünüldüğünde sosyal zekâ ve liderlik arasında olumlu bir ilişki olduğu söylenebilir. Nitekim Kobe ve diğerleri, (2001) tarafından yapılan araştırma da bu görüşü desteklemektedir.

Okul müdürleri arasındaki farklılıklar düşünüldüğünde sonradan değiştirilemeyen ya da geliştirilemeyen iki temel değişken cinsiyet ve yaştır. Bu iki değişken dışındaki diğer tüm değişkenler bireysel çaba ya da eğitimler ile değiştirilebilir ya da geliştirilebilir. Bu yüzden araştırmada odağın dağılmaması amacıyla sadece bu temel değişkenlerin ele alınmasına karar verilmiştir. Millî Eğitim Bakanlığı'na bağlı devlet okullarında okul müdürü olabilme şartlarına bakıldığı zaman, farklı şartlar ile birlikte en az bir yıl müdür yardımcısı olarak görev yapmış olmak şartı bulunmaktadır. Müdür yardımcısı olabilmek için de adaylık dahil en az iki yıl görev yapmış olmak başvuru için yeterlidir (MEB, 2021). Bu açıdan bakıldığında bakanlıkta üç yıldır çalışan bir öğretmen okul müdürü olabilmektedir. Bu da bize okul müdürleri arasında yaş aralığının oldukça geniş olduğunu göstermektedir. Bu açıdan okul müdürlerinin yaşlarına göre duygusal zekâ, sosyal zekâ ve liderlik stillerinin incelenmesi, mesleğe yeni başlayan okul müdürleri ile meslekte uzun yıllar çalışmış okul müdürleri arasındaki farkı ortaya koyması açısından önemli olabilir. Yine aynı şekilde okul müdürlerinin cinsiyetlerine göre duygusal zekâ, sosyal zekâ ve liderlik stillerinin incelenmesi, erkek okul müdürleri ile kadın okul müdürleri arasındaki farkı ortaya koyması açısından önemli olabilir. Yapılan araştırmalar incelendiğinde, dönüşümcü liderlik ve duygusal zekâ ilişkisini inceleyen pek çok araştırmaya (Çaka ve Arbak, 2003; Ducket ve Macfarlane, 2003; Downey ve diğerleri, 2006; Erkuş ve Günlü, 2008; Gardner ve Stough, 2002; Sosik ve Megerian, 1999) rastlanırken ulaşılabilen çalışmalar içerisinde dönüşümcü liderlik ve sosyal zekâ ilişkisini inceleyen bir çalışmaya rastlanmamıştır. Benzer şekilde sürdürümcü liderlik ve serbestlik tanıyan liderlik ile duygusal zekâ yetenekleri ve sosyal zekâ yeteneklerinin incelendiği bir çalışmaya da rastlanmamıştır. Bu açıdan eğitim yöneticilerinin duygusal zekâ yetenekleri ve sosyal zekâ yetenekleri ile liderlik stilleri arasındaki ilişkinin incelenmesinin literatüre bu anlamda katkı sunması açısından oldukça önemli olduğu düşünülmektedir. Aynı zamanda bu yönde yapılan çalışmaların eğitim yöneticilerinin mesleki sorumluluklarını yerine getirmelerine etki eden özelliklerin farkına varmalarına ve dolayısıyla okulların başarısına katkı sağlayacağı düşünülmektedir. Bu nedenle bu araştırmanın amacı, eğitim yöneticilerinin 
duygusal zekâ ve sosyal zekâ yeteneklerinin cinsiyet ve yaş değişkenleri açısından anlamlı düzeyde farklılaşıp farklılaşmadığını, eğitim yöneticilerinin duygusal zekâ ve sosyal zekâ yeteneklerinin liderlik stillerini anlamlı düzeyde yordayıp yordamadığını belirlemektir.

\section{Yöntem}

$\mathrm{Bu}$ araştırma eğitim yöneticilerinin duygusal zekâ ve sosyal zekâ yetenekleri ile liderlik stilleri arasındaki ilişkiyi incelemek için hazırlanmış, ilişkisel tarama modelinde bir araştırmadır. Tarama modeli, "geçmişte ya da halen varolan bir durumu varolduğu şekliyle belirtmeyi amaçlayan araştırma yaklaşımlarıdır. Bu modelde önemli olan varolanı değiştirmeye kalkmadan gözlemleyebilmektedir" (Karasar, 2002). İlişkisel tarama modelleri ise "iki ya da daha çok sayıdaki değişken arasında birlikte değişim varlığını veya derecesini belirlemeyi amaçlayan araştırma modelleridir" (Karasar, 2002).

İstanbul Medeniyet Üniversitesi'nin 07/06/2021 tarih ve 2021/06-29 sayılı kararı doğrultusunda bu çalışma etik açıdan uygundur.

\section{Evren ve Örneklem}

Araştırmanın evrenini; 2019-2020 eğitim-öğretim yılı İstanbul İli Avcılar, Beyoğlu, Çatalca, Esenyurt ve Güngören İlçelerinde resmi okullarda (devlet okulları) görev yapan 397 okul müdürü oluşturmaktadır.

Araştırmanın örneklemini; 2019-2020 eğitim-öğretim yılı İstanbul İli Avcılar, Beyoğlu, Çatalca, Esenyurt ve Güngören İlçelerinde görev yapan ve evrenden seçkisiz olarak belirlenen 67 kadın ve 210 erkek olmak üzere toplam 277 okul müdürü oluşturmaktadır. Eğitim yöneticilerinden 78 kişi 23-40 yaş arasında, 119 kişi 41-50 yaş arasında ve 80 kişi 51 yaş ve üzerindedir. Ayrıca araştırmaya katılan eğitim yöneticilerinin 9'u anaokulunda, 56'sı ilkokulda, 111'i ortaokulda, 32'si mesleki ve teknik anadolu lisesinde, 10'u çok programlı anadolu lisesinde, 11'i anadolu imam hatip lisesinde, 25'i proje ve uygulama lisesinde, 2'si sosyal bilimler ya da fen lisesinde, 4'ü anadolu lisesinde ve 17'si diğer eğitim kurumlarında görev yapmaktadır.

Araştırma örneklemi; ulaşım kolaylıkları, zaman ve mali kaynaklar açısından daha ekonomik olması nedeniyle Avcılar, Beyoğlu, Çatalca, Esenyurt ve Güngören ilçelerindeki resmi okullar (devlet okulları) olarak belirlenmiştir.

\section{Veri Toplama Araçları}

Araştırmanın verilerini toplamak amacıyla Wong \& Law Duygusal Zekâ Ölçeği (WLEIS), Tromso Sosyal Zekâ Ölçeği ve Çok Faktörlü Liderlik Ölçeği kullanılmıştır.

WLEIS (Wong \& Law Duygusal Zekâ Ölçeği): Araştırmada, Salovey ve Mayer duygusal zekâ teorisini temel alan Wong ve Law tarafından geliştirilen Deniz (2012)'in Türkçeye çevirip geçerlilik ve güvenilirlik analizlerini yapmış olduğu ve 4 boyut ve 16 maddeden oluşan, Duygusal Zekâ Ölçeği kullanılmıştır. Duygusal Zekâ Ölçeği 5‘li Likert tipindeki olup kendi duygularını değerlendirme (4 madde), başkalarının duygularını değerlendirme (4 madde), duyguların kullanılması (4 madde), duyguların düzenlenmesi (4 madde) olmak üzere 4 alt boyuttan oluşmaktadır. Ölçek maddelerinin puanlanmasında 1 "kesinlikle katılmıyorum", 5 ise "kesinlikle katılıyorum"anlamına gelmektedir. Ayrıca ölçekte ters kodlanmış madde bulunmamaktadır.Söz konusu orjinal ölçeğin güvenilirlik analizi sonuçlarına göre; kendi duygularını değerlendirmenin Cronbach Alfa güvenilirlik katsayısının 0,89; duyguların kullanılmasının 0,88; duyguların düzenlenmesinin 0,76; başkalarının duygularının değerlendirmenin ise 0,85 olduğu belirlenmiştir (Wong ve Law, 2002; akt. Hırlak vd. 2018).

Bu araştırmada kullanılan "Wong \& Law Duygusal Zekâ Ölçeği" nin Cronbach-Alpha katsayıları iç tutarlılık için hesaplanmış ve genel güvenilirliğinin $\alpha=0,857$ olduğu görülmektedir. Ölçeğin alt boyutlarının güvenilirlikleri incelendiğinde, "Kendi Duygularını Değerlendirme" alt boyutunun güvenilirliği $\alpha=0,72$, "Başkalarının Duygularını Değerlendirme" alt boyutunun güvenilirliği $\alpha=0,77$, "Duygularını Kullanma" alt boyutunun güvenilirliği $\alpha=0,82$ ve "Duygularını Düzenleme" alt boyutunun güvenilirliği $\alpha=0,84$ bulunmuştur. Cronbach-Alpha değerinin 0,8 'den büyük olması ölçek güvenirliğinin "çok iyi" olduğunu 
gösterir (George ve Mallery, 2010). Ayrıca çalışmada ölçeğin dört boyutlu yapısı için doğrulayıcı faktör analizi $(\mathrm{x2} / \mathrm{sd}=3,81 ; \mathrm{RMSEA}=.08 ; \mathrm{CFI}=.95 ; \mathrm{NNFI}=.94 ; \mathrm{NFI}=.95 ; \mathrm{SRMR}=.08$ yapılmış, elde edilen uyum değerlerinin kabul edilebilir uyum değerleri (Bollen, 1989; Browne ve Cudeck, 1993; Kline, 2011) arasında olduğu ve geçerlik şartlarını taşıdığı gözlenmiştir.

Tromso Sosyal Zekâ Ölçeği: Tromso Sosyal Zekâ Ölçeği (Tromso Social Intelligence Scale) Silvera ve diğerleri (2001) tarafından sosyal zekâ düzeyini ölçmek üzere geliştirilmiş bir ölçme aracıdır. Ölçek Türkçeye Doğan ve Çetin (2009) tarafından uyarlanmıştır. Ölçme aracı "sosyal bilgi, sosyal beceri ve sosyal farkındalık" olmak üzere üç boyut ve 21 ifadeden oluşmaktadır. Ölçeğin yapı geçerliğine açımlayıcı ve doğrulayıcı faktör analizi ile bakılmıştır. Ölçüt geçerliğini sınamak amacıyla sosyal beceri envanteri ile korelasyonuna bakılmıştır. Ölçeğin güvenirliği ise iç tutarlılık, test yarılama ve test tekrar test yöntemleriyle hesaplanmıştır. Yapılan faktör analizi sonucunda TSIS, orijinaline benzer şekilde üç faktörlü bir yapı ortaya çıkmıştır. Uyum geçerliği bağlamında sosyal beceri envanteri ile TSZÖ arasında .51 korelasyon bulunmuştur. Ölçeğin iç tutarlılık kat sayısı .83 , test tekrar test .80 ve test yarılama sonucu .75 olarak bulunmuştur (Doğan ve Çetin, 2009).

Bu araştırmada kullanılan "Tromso Soyal Zekâ Ölçeği" nin Cronbach-Alpha katsayıları iç tutarlılık için hesaplanmış ve genel güvenilirliğinin $\alpha=0,90$ olduğu görülmektedir. Ölçeğin alt boyutlarının güvenilirlikleri incelendiğinde, "Sosyal Bilgi Süreci" alt boyutunun güvenilirliği $\alpha=0,78$, "Sosyal Beceri" alt boyutunun güvenilirliği $\alpha=0,71$ ve "Sosyal Farkındalık" alt boyutunun güvenilirliği $\alpha=0,78$ bulunmuştur. CronbachAlpha değerinin 0,6 - 0,8 arasında olması ölçek güvenirliğinin "iyi" olduğunu gösterir (George ve Mallery, 2010). Ayrıca çalışmada ölçeğin üç boyutlu yapısı için doğrulayıcı faktör analizi (x2 /sd = 3,63; RMSEA = .07; $\mathrm{CFI}=.94 ; \mathrm{NNFI}=.95 ; \mathrm{NFI}=.97 ; \mathrm{SRMR}=.07)$ yapılmış, elde edilen uyum değerlerinin kabul edilebilir uyum değerleri (Bollen, 1989; Browne ve Cudeck, 1993; Kline, 2011) arasında olduğu ve geçerlik şartlarını taşıdığı gözlenmiştir.

Çok Faktörlï Liderlik Ölçeği: Bass ve Avolio (1990) tarafından Durumsal Liderlik Teorisi kapsamında kişilerin liderlik stillerinin tespiti için geliştirilen ölçek Türkçeye Akdoğan (2002) tarafından açımlayıcı faktör analizi yöntemi ile tekrar gözden geçirilmiş ve sonuç olarak ölçeğin Türkçe formu 5’li Likert tipi toplam 36 madde, 3 bileşenden (Dönüşümcü Liderlik, Sürdürümcü Liderlik ve Serbestlik Tanıyan Liderlik) oluşmaktadır. Ölçeğin iç tutarlılık düzeyi Cronbach Alpha değeri 0.70 ile 0.91 arasında değişmektedir (Akdoğan, 2002).

Bu araştırmada kullanılan "Çok Faktörlü Liderlik Ölçeği" nin Cronbach-Alpha katsayıları iç tutarlılık için hesaplanmış ve ölçeğin alt boyutlarının güvenilirlikleri incelendiğinde, "Dönüşümcü Liderlik" alt boyutunun güvenilirliği $\alpha=0,88$, "Sürdürümcü Liderlik" alt boyutunun güvenilirliği $\alpha=0,72$ ve "Serbestlik Tanıyan Liderlik" alt boyutunun güvenilirliği $\alpha=0,71$ bulunmuştur. Cronbach-Alpha değerinin 0,6-0,8 arasında olması ölçek güvenirliğinin "iyi" olduğunu gösterir (George ve Mallery, 2010). Ayrıca çalışmada ölçeğin üç boyutlu yapısı için doğrulayıcı faktör analizi $(x 2 / \mathrm{sd}=3,97$; RMSEA = .08; CFI = .95; NNFI = .94; NFI $=.93 ;$ SRMR = .08) yapılmış, elde edilen uyum değerlerinin kabul edilebilir uyum değerleri (Bollen, 1989; Browne ve Cudeck, 1993; Kline, 2011) arasında olduğu ve geçerlik şartlarını taşıdığı gözlenmiştir.

\section{Verilerin Analizi}

Ölçekler ile toplanan veriler SPSS 18.0 paket programıla bilgisayarda analiz edilmiştir. Veriler analiz edilmeden önce, Wong \& Law Duygusal Zekâ Ölçeğinin alt boyutlarının, Tromso Sosyal Zekâ Ölçeğinin alt boyutlarının ve Çok Faktörlü Liderlik Ölçeğinin alt boyutlarının normal dağılım gösterip göstermedikleri Kolmogorov-Smirnov Testi ile test edilmiş ve sonuçları Tablo 1'de sunulmuştur. Verilerin analizinde bağımsız örneklemler için T testi, tek yönlü varyans analizi, Tukey testi ve çok değişkenli doğrusal regresyon analizi kullanılmıştır. 
Baran Barış YILDIZ, Tevfik Sertaç ÇELIKKÇEKEN \& Mesut GÜLPER

Tablo 1. Wong \& Law Duygusal Zekâ Ölçeği, Tromso Sosyal Zekâ Ölçeği ve Çok Faktörlü Liderlik Ölçeğinin Kolomogorov-Smirnov Testi Sonuçları

\begin{tabular}{|c|c|c|c|c|c|c|}
\hline \multirow{2}{*}{ Ölçek } & \multirow{2}{*}{ Alt Boyut } & \multicolumn{5}{|c|}{ Kolmogorov-Smirnow } \\
\hline & & Statistic & Df & $\mathbf{p}$ & Basıklık & Çarpıklık \\
\hline \multirow{5}{*}{ 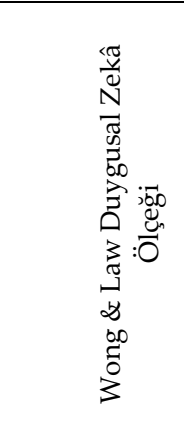 } & $\begin{array}{ll}\text { Kendi } & \text { Duygularını } \\
\text { Değerlendirme } & \end{array}$ & ,247 & 277 & ,000 &,- 224 & $-1,567$ \\
\hline & $\begin{array}{l}\text { Başkalarının Duygularını } \\
\text { Değerlendirme }\end{array}$ & 203 & 277 & ,000 & ,095 & $-1,414$ \\
\hline & Duygularını Kullanma & ,129 & 277 & ,000 &,- 556 &,- 085 \\
\hline & Duygularını Düzenleme & 167 & 277 & ,000 &,- 007 &,- 915 \\
\hline & Tüm Ölçek & ,122 & 277 & ,000 & 188 & $-1,099$ \\
\hline \multirow{4}{*}{ 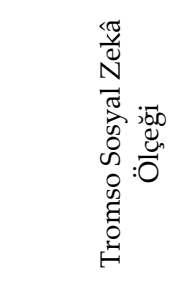 } & Sosyal Bilgi Süreci & ,110 & 277 &, 000 & 137 &,- 773 \\
\hline & Sosyal Beceri & 111 & 277 &, 000 &,- 032 &,- 729 \\
\hline & Sosyal Farkındalık & ,105 & 277 & ,000 &,- 655 & 143 \\
\hline & Tüm Ölçek & ,076 & 277 & ,001 &,- 244 &,- 629 \\
\hline \multirow{4}{*}{ 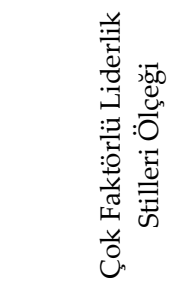 } & Dönüşümcü Liderlik & 152 & 277 & ,000 & 057 & $-1,277$ \\
\hline & Sürdürümcü Liderlik & 129 & 277 & ,000 &,- 355 &,- 499 \\
\hline & Serbestlik Tanıyan Liderlik & 114 & 277 &, 000 & 454 &, 370 \\
\hline & Tüm Ölçek & ,066 & 277 & ,005 &, 030 &,- 746 \\
\hline
\end{tabular}

Tablo 1'de de görüldüğü gibi Wong \& Law Duygusal Zekâ Ölçeği, Tromso Sosyal Zekâ Ölçeği ve Çok Faktörlü Liderlik Ölçeği'nin tüm alt boyutlarının Kolmogorov-Smirnov testi sonuçları anlamlı çıkmıştır $(\mathrm{p}<.05)$. Bu durumda verilerin normallik varsayımlarını karşılamadığı söylenebilmektedir. Ancak, George ve Mallery (2010)'e göre Kolmogorov-Smirnov testi sonucunda anlamlı çıksa da basıklık ve çarpıklık değerleri +2.00-2.00 aralığında yer alıyorsa verilerin normal dağılım gösterdiği kabul edilmektedir. Buna göre ölçeklerin tüm alt boyutlarının basıklık ve çarpıklık değerleri $+2,00-2,00$ aralığında olduğu için normal dağıldığı kabul edilmiş ve verilerin analizinde parametrik testler kullanılmıştır.

\section{Bulgular}

Cinsiyet değişkenine göre eğitim yöneticilerinin duygusal zekâ yetenekleri, sosyal zekâ yetenekleri ve liderlik stilleri puanlarının karşılaştırılmasında normal dağılım varsayımları karşılandığı için parametrik istatistik tekniklerinden bağımsız örneklemler için T-Testi kullanılmıştır.

Yaş değişkenine göre ise eğitim yöneticilerinin duygusal zekâ yetenekleri, sosyal zekâ yetenekleri ve liderlik stilleri puanlarını karşılaştırmadan önce grupların homojenliklerinin denkliğini ortaya koymak amacıyla Levene F Testi (homojenlik) testi uygulanmıştır. Tüm gruplar arasında anlamlı farklılık çıkması nedeniyle örneklemden elde edilen dağılımların benzer homojenliklerde olmadığı ve normal dağılım varsayımlarını karşıladığı için parametrik istatistik tekniklerinden tek yönlü varyans analizi kullanılmıştır. Bağımsız örneklemler için $T$ testi sonuçları tablo 2'de tek yönlü varyans analizi sonuçları ise tablo 3'de verilmiştir. 
Okul Yöneticilerinin Duygusal ve Sosyal Zekâları ile Liderlik Stilleri Arasındaki...

Tablo 2. Eğitim Yöneticilerinin Duygusal Zekâ Yetenekleri, Sosyal Zekâ Yetenekleri ve Liderlik Stillerinin Cinsiyet Değişkenine Göre T Testi Sonuçları

\begin{tabular}{|c|c|c|c|c|c|c|c|}
\hline & Grup & $\mathbf{N}$ & $\overline{\bar{X}}$ & $S$ & sd & $t$ & $p$ \\
\hline \multirow{2}{*}{ KDD } & Erkek & 210 & 4,66 & ,31 & \multirow{2}{*}{275} & \multirow{2}{*}{$-1,029$} & \multirow{2}{*}{,304 } \\
\hline & Kadın & 67 & 4,70 & ,29 & & & \\
\hline \multirow{2}{*}{ BDD } & Erkek & 210 & 4,35 & 44 & \multirow{2}{*}{275} & \multirow{2}{*}{$-3,509$} & \multirow{2}{*}{, $000^{*}$} \\
\hline & Kadın & 67 & 4,56 & ,39 & & & \\
\hline \multirow{2}{*}{ DK } & Erkek & 210 & 4,29 & ,53 & \multirow{2}{*}{275} & \multirow{2}{*}{$-1,424$} & \multirow{2}{*}{ 156 } \\
\hline & Kadın & 67 & 4,39 &, 52 & & & \\
\hline \multirow{2}{*}{$\mathrm{DD}$} & Erkek & 210 & 4,29 & ,46 & \multirow{2}{*}{275} & \multirow{2}{*}{1,082} & \multirow{2}{*}{,327 } \\
\hline & Kadın & 67 & 4,21 &, 55 & & & \\
\hline \multirow{2}{*}{ SBS } & Erkek & 210 & 3,99 & ,45 & \multirow{2}{*}{275} & \multirow{2}{*}{$-1,198$} & \multirow{2}{*}{ 232 } \\
\hline & Kadın & 67 & 4,21 & ,55 & & & \\
\hline \multirow{2}{*}{ SB } & Erkek & 210 & 4,03 &, 54 & \multirow{2}{*}{275} & \multirow{2}{*}{$-1,153$} & \multirow{2}{*}{ 250 } \\
\hline & Kadın & 67 & 4,12 &, 56 & & & \\
\hline \multirow{2}{*}{ SF } & Erkek & 210 & 3,89 & 63 & \multirow{2}{*}{275} & \multirow{2}{*}{$-2,866$} & \multirow{2}{*}{, $007^{*}$} \\
\hline & Kadın & 67 & 4,15 & 69 & & & \\
\hline \multirow{2}{*}{$\mathrm{DL}$} & Erkek & 210 & 4,38 & ,38 & \multirow{2}{*}{275} & \multirow{2}{*}{$-2,468$} & \multirow{2}{*}{, $009^{*}$} \\
\hline & Kadın & 67 & 4,51 & ,33 & & & \\
\hline \multirow{2}{*}{ SL } & Erkek & 210 & 3,51 & ,33 & \multirow{2}{*}{275} & \multirow{2}{*}{3,759} & $001 *$ \\
\hline & Kadın & 67 & 3,32 & ,41 & & & , \\
\hline STI & Erkek & 210 & 2,19 & 66 & 275 & 1664 & 050 \\
\hline SIL & Kadın & 67 & 2,04 & ,47 & 273 & 1,004 & , \\
\hline
\end{tabular}

${ }^{*} \mathrm{p}<.05$

Tablo 2 incelendiğinde uygulanan bağımsız örneklemler T testi sonucunda duygusal zekânın alt boyutu olan başkalarının duygularını değerlendirme puan ortalamalarının cinsiyet değişkenine göre anlamlı olarak farklılaştığı bulunmuştur $(\mathrm{t}=-3,509, \mathrm{p}<.05)$. Kadın eğitim yöneticilerinin başkalarının duygularını değerlendirme puan ortalamalarının erkek eğitim yöneticilerinin puan ortalamalarından anlamlı olarak yüksek olduğu bulunmuştur.

Sosyal zekânın alt boyutu olan sosyal farkındalık puan ortalamalarının cinsiyet değişkenine göre anlamlı olarak farklılaştığı tespit edilmiştir $(t=-2,866, p<.05)$. Kadın eğitim yöneticilerinin sosyal farkındalık puan ortalamalarının erkek eğitim yöneticilerinin puan ortalamalarından anlamlı olarak yüksek olduğu bulunmuştur.

Liderlik stillerinden dönüşümcü liderlik ve sürdürümcü liderlik puan ortalamalarının cinsiyet değişkenine göre anlamlı olarak farklılaştığı bulunmuştur. Kadın eğitim yöneticilerinin dönüşümcü liderlik puan ortalamalarının erkek eğitim yöneticilerin puan ortalamalarından anlamlı olarak yüksek olduğu tespit edilmiştir $(\mathrm{t}=-2,468, \mathrm{p}<.05)$. Erkek eğitim yöneticilerinin sürdürümcü liderlik puan ortalamalarının kadın eğitim yöneticilerin puan ortalamalarından anlamlı olarak yüksek olduğu tespit edilmiştir $(t=3,759, p<.05)$.

Duygusal zekânın alt boyutlarından kendi duygularını değerlendirme, duygularını kullanma, duygularını düzenleme, sosyal zekanın alt boyutlarından sosyal bilgi süreci, sosyal beceri ve liderlik stillerinden serbestlik tanıan liderliğin cinsiyet değişkenine göre anlamlı olarak farklılaşmadığı bulunmuştur. 
Tablo 3. Eğitim Yöneticilerinin Duygusal Zekâ Yetenekleri, Sosyal Zekâ Yetenekleri ve Liderlik Stillerinin Yaş Değişkenine Göre Varyans Analizi ve Tukey Testi Sonuçları

\begin{tabular}{|c|c|c|c|c|c|c|}
\hline Değişken & Grup & $\mathbf{N}$ & $\bar{x}$ & s & $\mathbf{F}$ & Tukey Testi Sonuçları \\
\hline \multirow{3}{*}{ KDD } & 23-40 Aras1 & 78 & 4,74 & ,29 & \multirow{3}{*}{$6,658^{*}$} & \multirow{3}{*}{$1-3,2-3$} \\
\hline & 41-50 Aras1 & 119 & 4,68 &, 30 & & \\
\hline & 51 ve Üzeri & 80 & 4,57 &, 30 & & \\
\hline \multirow{3}{*}{ BDD } & 23-40 Arası & 78 & 4,48 & 45 & \multirow{3}{*}{$3,533^{*}$} & \multirow{3}{*}{$1-2$} \\
\hline & 41-50 Aras1 & 119 & 4,32 & ,43 & & \\
\hline & 51 ve Üzeri & 80 & 4,45 &, 42 & & \\
\hline \multirow{3}{*}{ DK } & 23-40 Aras1 & 78 & 4,47 & 42 & \multirow{3}{*}{$4,933^{*}$} & \multirow{3}{*}{$1-2$} \\
\hline & 41-50 Aras1 & 119 & 4,23 &, 57 & & \\
\hline & 51 ve Üzeri & 80 & 4,28 &, 53 & & \\
\hline \multirow{3}{*}{ DD } & 23-40 Arası & 78 & 4,20 & ,51 & \multirow{3}{*}{2,651} & \\
\hline & 41-50 Arası & 119 & 4,24 & ,49 & & ------ \\
\hline & 51 ve Üzeri & 80 & 4,37 & ,42 & & \\
\hline \multirow{3}{*}{ SBS } & 23-40 Arası & 78 & 4,05 & 40 & \multirow{3}{*}{443} & \\
\hline & 41-50 Arası & 119 & 3,99 &, 50 & & ------ \\
\hline & 51 ve Üzeri & 80 & 4,01 &, 47 & & \\
\hline \multirow{3}{*}{ SB } & 23-40 Aras1 & 78 & 4,11 &, 58 & \multirow{3}{*}{2,484} & \\
\hline & 41-50 Aras1 & 119 & 3,97 & 60 & & ------ \\
\hline & 51 ve Üzeri & 80 & 4,12 & ,41 & & \\
\hline \multirow{3}{*}{ SF } & 23-40 Arası & 78 & 4,22 & 65 & \multirow{3}{*}{$10,359^{*}$} & \multirow{3}{*}{$1-2,1-3$} \\
\hline & 41-50 Aras1 & 119 & 3,80 & 62 & & \\
\hline & 51 ve Üzeri & 80 & 3,93 & ,61 & & \\
\hline \multirow{3}{*}{ DL } & 23-40 Aras1 & 78 & 4,47 & ,34 & \multirow{3}{*}{1,652} & \multirow{3}{*}{------ } \\
\hline & 41-50 Arası & 119 & 4,41 & ,41 & & \\
\hline & 51 ve Üzeri & 80 & 4,36 &, 35 & & \\
\hline \multirow{3}{*}{ SL } & 23-40 Aras1 & 78 & 3,34 & ,37 & \multirow{3}{*}{$6,596^{*}$} & \multirow{3}{*}{$2-1,3-1$} \\
\hline & 41-50 Arası & 119 & 3,52 &, 36 & & \\
\hline & 51 ve Üzeri & 80 & 3,50 &, 32 & & \\
\hline \multirow{3}{*}{ STL } & 23-40 Aras1 & 78 & 2,00 & ,55 & \multirow{3}{*}{$6,991^{*}$} & \multirow{3}{*}{$3-1,3-2$} \\
\hline & 41-50 Aras1 & 119 & 2,11 &, 56 & & \\
\hline & 51 ve Üzeri & 80 & 2,36 & ,73 & & \\
\hline
\end{tabular}

${ }^{*} \mathrm{p}<.05$

Tablo 3 incelendiğinde uygulanan varyans analizi sonucunda duygusal zekâ alt boyutlarından kendi duygularını değerlendirme, başkalarının duygularını değerlendirme ve duygularını kullanma, sosyal zekâ alt boyutlarından sosyal farkındalık ve liderlik stillerinden sürdürümcü liderlik ve serbestlik tanıyan liderlik puan ortalamalarının yaş değişkenine göre anlamlı olarak farklılaştığ kaynağını belirlemek amacıyla Tukey testi uygulanmıştır. 23-40 Yaş arasında olan eğitim yöneticilerinin kendi duygularını değerlendirme puan ortalamalarının 41-50 yaş arasında olan eğitim yöneticilerinin ortalamalarından ve 41-50 yaş arasında olan eğitim yöneticilerinin kendi duygularını değerlendirme puan ortalamalarının 51 ve üzeri yaşta olan eğitim yöneticilerinin ortalamalarından anlamlı düzeyde yüksek olduğu bulunmuştur. Yapılan diğer ikili karşılaştırmalarda anlamlı düzeyde farklılaşma tespit edilmemiştir. Duygusal zekânın başkalarının duygularını değerlendirme alt boyutunda, 23-40 yaş arasında olan eğitim yöneticilerinin puan ortalamalarının 41-50 yaş arasında olan eğitim yöneticilerinin ortalamalarından anlamlı düzeyde yüksek olduğu bulunmuştur. Yapılan diğer ikili karşılaştırmalarda anlamlı düzeyde farklılaşma görülmemiştir. Duygularını kullanma alt boyutunda, 23-40 yaş arasında olan eğitim yöneticilerinin puan ortalamalarının 41-50 yaş arasında olan eğitim yöneticilerinin ortalamalarından anlamlı düzeyde yüksek olduğu bulunmuştur. Yapılan diğer ikili karşılaştırmalarda anlamlı düzeyde farklılaşma görülmemiştir.

Sosyal zekânın sosyal farkındalık alt boyutunda, 23-40 yaş arasında olan eğitim yöneticilerinin puan ortalamalarının 41-50 arasında ve 51 ve üzeri yaşta olan eğitim yöneticilerinin ortalamalarından anlamlı 
düzeyde yüksek olduğu saptanmıştır. Yapılan diğer ikili karşılaştırmalarda anlamlı düzeyde farklılaşmanın olmadığ1 görülmüştür.

Liderlik stillerinden sürdürümcü liderlikte, 41-50 yaş arasında ve 51 ve üzeri yaşta olan eğitim yöneticilerinin puan ortalamalarının 23-40 yaş arasında olan eğitim yöneticilerinin ortalamalarında anlamlı düzeyde yüksek olduğu bulunmuştur. Yapılan diğer ikili karşılaştırmalarda anlamlı düzeyde farklılaşma görülmemiştir. Serbestlik tanıyan liderlikte, 51 ve üzeri yaşta olan eğitim yöneticilerinin puan ortalamalarının 23-40 yaş ve 41-50 yaş arasında olan eğitim yöneticilerinin ortalamalarından anlamlı düzeyde yüksek olduğu bulunmuştur. Yapılan diğer ikili karşılaştırmalarda anlamlı düzeyde farklılaşma saptanmamıştır.

Duygusal zekânın duygularını düzenleme alt boyutu, sosyal zekanın sosyal bilgi süreci, sosyal beceri alt boyutları ve liderlik stillerinden dönüşümcü liderlik stilinin yaş değişkenine göre anlamlı düzeyde farklılaşmadığı bulunmuştur.

Duygusal zekâ yeteneklerinin dönüşümcü liderlik stilini açıklama ve yordama gücüne ilişkin yapılan çok değişkenli doğrusal regresyon analizi sonuçları Tablo 4'de sunulmuştur.

Tablo 4. Duygusal Zekâ Yeteneklerinin Dönüşümcü Liderlik Stilini Açıklama ve Yordama Gücü

\begin{tabular}{|c|c|c|c|c|c|c|c|}
\hline Değişken & B & $\begin{array}{l}\text { Standart } \\
\text { Hata }\end{array}$ & $\beta$ & $\mathbf{t}$ & $\mathbf{P}$ & $\begin{array}{c}\text { İkili } \\
\text { r }\end{array}$ & $\begin{array}{c}\text { Kismi } \\
\text { r }\end{array}$ \\
\hline Sabit & 960 & ,755 & - & 1,273 & ,365 & - & - \\
\hline KDD & 152 & ,290 & ,125 & 1,971 & ,050 & ,442 & 119 \\
\hline BDD & 296 & ,077 & ,348 & 5,845 & ,000 & ,543 & ,334 \\
\hline DK & 154 & ,051 & ,218 & 3,450 & ,001 & ,480 & ,205 \\
\hline $\mathrm{DD}$ & ,063 & ,045 & ,082 & 1,504 & ,134 & ,341 & ,091 \\
\hline
\end{tabular}

Tablo 4 incelendiğinde eğitim yöneticilerinin duygusal zekâ yeteneklerinin bütün olarak dönüşümcü liderlik stili puanlarını yordadığı görülmektedir $\left(\mathrm{R}=, 614, \mathrm{R}^{2}=367, \mathrm{~F}=41,080, \mathrm{p}<, 050\right)$. Duygusal zekâ yetenekleri (Kendi duygularını değerlendirme, Başkalarının duygularını değerlendirme, Duygularını kullanma, Duygularını düzenleme) dönüşümcü liderlik stilindeki toplam varyansın \%36,7'sini açılamaktadır. Regresyon katsayılarının anlamlılığına ilişkin $t$ testi sonuçları incelendiğinde en önemli yordayıcının başkalarının duygularını değerlendirme $(\beta=, 348)$ daha sonra ise duygularını kullanma $(\beta=, 218)$ olduğu görülmüştür. Duygusal zekâ yeteneklerinden kendi duygularını değerlendirme ve duygularını düzenlemenin ise dönüşümcü liderlik stilini yordamadığı görülmüştür.

Duygusal zekâ yeteneklerinin sürdürümcü liderlik stilini açılama ve yordama gücüne ilişkin yapılan çok değişkenli doğrusal regresyon analizi sonuçları Tablo 5'de sunulmuştur.

Tablo 5. Duygusal Zekâ Yeteneklerinin Sürdürümcü Liderlik Stilini Açılama ve Yordama Gücü

\begin{tabular}{|c|c|c|c|c|c|c|c|}
\hline Değişken & B & $\begin{array}{l}\text { Standart } \\
\text { Hata }\end{array}$ & $\beta$ & $t$ & $\mathbf{P}$ & $\begin{array}{c}\text { İkili } \\
\text { r }\end{array}$ & $\begin{array}{c}\text { K1smi } \\
r\end{array}$ \\
\hline Sabit & 1,171 & ,878 & - & 1,856 & 670 & - & - \\
\hline KDD & ,097 & ,093 & ,082 & 1,046 & 296 &,- 002 & ,063 \\
\hline BDD &,- 158 & 061 & -192 & $-2,592$ & ,010 & -,135 & -,155 \\
\hline DK &,- 031 & ,054 & -,045 &,- 569 & ,570 &,- 059 &,- 034 \\
\hline $\mathrm{DD}$ & ,067 & ,051 & ,090 & 1,326 & 186 & ,017 & ,080 \\
\hline
\end{tabular}

$\mathrm{R}=, 173 \mathrm{R}^{2}=, 016 \quad \mathrm{~F}=2,107 \quad \mathrm{p}=, 080$ 
Tablo 5 incelendiğinde eğitim yöneticilerinin duygusal zekâ yeteneklerinin bütün olarak sürdürümcü liderlik stili puanlarını yordamadığı görülmektedir $\left(R=, 173, R^{2}=, 016, F=2,107, p>, 050\right)$.

Duygusal zekâ yeteneklerinin serbestlik tanıyan liderlik stilini açıklama ve yordama gücüne ilişkin yapılan çok değişkenli doğrusal regresyon analizi sonuçları Tablo 6'da sunulmuştur.

Tablo 6. Duygusal Zekâ Yeteneklerinin Serbestlik Tanıyan Liderlik Stilini Açıklama ve Yordama Gücü

\begin{tabular}{|c|c|c|c|c|c|c|c|}
\hline Değişken & B & $\begin{array}{l}\text { Standart } \\
\text { Hata }\end{array}$ & $\beta$ & $\mathbf{t}$ & $\mathbf{P}$ & $\begin{array}{c}\text { İkili } \\
\text { r }\end{array}$ & $\begin{array}{c}\text { Kismi } \\
\text { r }\end{array}$ \\
\hline Sabit & ,861 & 1,210 & - & 3,271 & ,391 & - & - \\
\hline KDD &,- 765 & ,139 &,- 377 & $-5,521$ & ,000 &,- 496 &,- 317 \\
\hline BDD &,- 131 & ,091 &,- 093 & $-1,442$ & ,150 &,- 306 &,- 087 \\
\hline $\mathrm{DK}$ &,- 186 & ,080 &,- 158 & $-2,315$ & ,021 &,- 418 &,- 139 \\
\hline $\mathrm{DD}$ & ,080 & ,076 & ,062 & 1,057 & ,291 &,- 146 & ,064 \\
\hline
\end{tabular}

$\mathrm{R}=, 522 \mathrm{R}^{2}=, 262 \quad \mathrm{~F}=7,369 \quad \mathrm{p}=, 000$

Tablo 6 incelendiğinde eğitim yöneticilerinin duygusal zekâ yeteneklerinin bütün olarak serbestlik tanıyan liderlik stili puanlarını yordadığı görülmektedir $\left(R=, 522, R^{2}=, 262, F=7,369, p<, 050\right)$. Duygusal zekâ yetenekleri (Kendi duygularını değerlendirme, Başkalarının duygularını değerlendirme, Duygularını kullanma, Duygularını düzenleme) serbestlik tanıyan liderlik stilindeki toplam varyansın \%26,2'sini açıklamaktadır. Regresyon katsayılarının anlamlılığına ilişkin t testi sonuçları incelendiğinde en önemli yordayıcının kendi duygularını değerlendirme $(\beta-, 377)$ daha sonra ise duygularını kullanma $(\beta=-, 158)$ olduğu görülmüştür. Duygusal zekâ yeteneklerinden başkalarının duygularını değerlendirme ve duygularını düzenlemenin ise serbestlik tanıyan liderlik stilini yordamadığı görülmüştür. Buna göre eğitim yöneticilerinin duygusal zekâ arttıkça serbestlik tanıyan liderlik davranışları azalmaktadır.

Sosyal zekâ yeteneklerinin dönüşümcü liderlik stilini açıklama ve yordama gücüne ilişkin yapılan çok değişkenli doğrusal regresyon analizi sonuçları Tablo 7'de sunulmuştur.

Tablo 7. Sosyal Zekâ Yeteneklerinin Dönüşümcü Liderlik Stilini Açıklama ve Yordama Gücü

\begin{tabular}{|c|c|c|c|c|c|c|c|}
\hline Değişken & B & Standart Hata & $\beta$ & $\mathbf{t}$ & $\mathbf{P}$ & $\begin{array}{l}\text { İkili } \\
\text { r }\end{array}$ & $\begin{array}{c}\text { Kismi } \\
\text { r }\end{array}$ \\
\hline Sabit & 971 & ,758 & - & 1,145 & ,357 & - & - \\
\hline SBS & 324 & ,046 & 404 & 7,030 & ,000 &, 576 & ,391 \\
\hline SB & 140 & 041 & ,205 & 3,375 & ,001 & ,486 & ,200 \\
\hline SF & 076 & ,035 & ,132 & 2,135 & ,034 & ,463 & ,128 \\
\hline
\end{tabular}

$\mathrm{R}=, 628 \mathrm{R}^{2}=, 387 \quad \mathrm{~F}=59,110 \quad \mathrm{p}=, 000$

Tablo 7 incelendiğinde eğitim yöneticilerinin sosyal zekâ yeteneklerinin bütün olarak dönüşümcü liderlik stili puanlarını yordadığı görülmektedir $\left(\mathrm{R}=, 628, \mathrm{R}^{2}=, 387, \mathrm{~F}=59,110, \mathrm{p}<, 050\right)$. Sosyal zekâ yetenekleri ( Sosyal Bilgi Süreci, Sosyal Beceri, Sosyal Farkındalık) dönüşümcü liderlik stilindeki toplam varyansın \%38,7'sini açıklamaktadır. Regresyon katsayılarının anlamlılı̆̆ına ilişkin t testi sonuçları incelendiğinde en önemli yordayıcının sosyal bilgi süreci $(\beta=, 404)$ sonra sosyal beceri $(\beta=, 205)$ daha sonra ise sosyal farkındalık $(\beta=, 132)$ olduğu görülmüştür.

Sosyal zekâ yeteneklerinin sürdürümcü liderlik stilini açıklama ve yordama gücüne ilişkin yapılan çokdeğişkenli doğrusal regresyon analizi sonuçları Tablo 8'de sunulmuştur. 
Okul Yöneticilerinin Duygusal ve Sosyal Zekâları ile Liderlik Stilleri Arasındaki...

Tablo 8. Sosyal Zekâ Yeteneklerinin Sürdürümcü Liderlik Stilini Açıklama ve Yordama Gücü

\begin{tabular}{cccccccc}
\hline Değişken & B & Standart Hata & $\boldsymbol{\beta}$ & $\mathbf{t}$ & $\mathbf{P}$ & $\begin{array}{c}\text { Ikili } \\
\mathbf{r}\end{array}$ & $\begin{array}{c}\text { Kismi } \\
\mathbf{r}\end{array}$ \\
\hline Sabit & 1,284 &, 898 & - &, 516 &, 261 & - & - \\
\hline SBS &, 039 &, 052 &, 051 &, 757 &, 450 &,- 173 &, 046 \\
\hline SB &,- 003 &, 047 &,- 004 &,- 060 &, 952 &,- 231 &,- 004 \\
\hline SF &,- 237 &, 040 &,- 428 & $-5,916$ &, 000 &,- 404 &,- 337 \\
\hline
\end{tabular}

$\mathrm{R}=, 406 \mathrm{R}^{2}=, 156 \quad \mathrm{~F}=17,962 \quad \mathrm{p}=, 000$

Tablo 8 incelendiğinde eğitim yöneticilerinin sosyal zekâ yeteneklerinin bütün olarak sürdürümcü liderlik stili puanlarını yordadığı görülmektedir $\left(\mathrm{R}=, 406, \mathrm{R}^{2}=, 156, \mathrm{~F}=17,962\right.$, $\left.\mathrm{p}<, 050\right)$. Sosyal zekâ yetenekleri ( Sosyal Bilgi Süreci, Sosyal Beceri, Sosyal Farkındalık) sürdürümcü liderlik stilindeki toplam varyansın \%15,6'sını açıklamaktadır. Regresyon katsayılarının anlamlılığına ilişkin t testi sonuçları incelendiğinde en önemli yordayıcının sosyal farkındalık $(\beta=-, 428)$ olduğu görülmüştür. Sosyal zekâ yeteneklerinden sosyal bilgi süreci ve sosyal becerinin ise sürdürümcü liderlik stilini yordamadığı görülmüştür. Buna göre eğitim yöneticilerinin sosyal zekâ yetenekleri arttıkça sürdürümcü liderlik davranışları azalmaktadır.

Sosyal zekâ yeteneklerinin serbestlik tanıyan liderlik stilini açıklama ve yordama gücüne ilişkin yapılan çok değişkenli doğrusal regresyon analizi sonuçları Tablo 9' da sunulmuştur.

Tablo 9. Sosyal Zekâ Yeteneklerinin Serbestlik Tanıyan Liderlik Stilini Açıklama ve Yordama Gücü

\begin{tabular}{cccccccc}
\hline Değişken & B & Standart Hata & $\boldsymbol{\beta}$ & $\mathbf{t}$ & $\mathbf{P}$ & İkili & Kismi \\
& & & & & & $\mathbf{r}$ \\
\hline Sabit & 1,185 &, 785 &, 465 & 1,987 &, 450 & - & - \\
\hline SBS &,- 315 &, 079 &,- 236 & $-3,960$ &, 000 &,- 444 &,- 233 \\
\hline SB &, 110 &, 071 &, 097 & 1,537 &, 125 &,- 313 &, 093 \\
\hline SF &,- 472 &, 061 &,- 494 & $-7,741$ &, 000 &,- 559 &,- 424 \\
\hline
\end{tabular}

$\mathrm{R}=, 592 \mathrm{R}^{2}=, 343 \mathrm{~F}=49,084 \quad \mathrm{p}=, 000$

Tablo 9 incelendiğinde eğitim yöneticilerinin sosyal zekâ yeteneklerinin bütün olarak serbestlik tanıyan liderlik stili puanlarını yordadığı görülmektedir $\left(\mathrm{R}=, 592, \mathrm{R}^{2}=, 343, \mathrm{~F}=49,084, \mathrm{p}<, 050\right)$. Sosyal zekâ yetenekleri ( Sosyal Bilgi Süreci, Sosyal Beceri, Sosyal Farkındalık) serbestlik tanıyan liderlik stilindeki toplam varyansın \%34,3'ünü açıklamaktadır. Regresyon katsayılarının anlamlılığına ilişkin $t$ testi sonuçları incelendiğinde en önemli yordayıcının sosyal farkındalık $(\beta=-, 494)$ olduğu daha sonra ise sosyal bilgi süreci $(\beta=-, 236)$ olduğu görülmüştür. Sosyal zekâ yeteneklerinden sosyal becerinin ise serbestlik tanıyan liderlik stilini yordamadığı görülmüştür. Buna göre eğitim yöneticilerinin sosyal zekâ yetenekleri arttıkça serbestlik tanıyan liderlik davranışları azalmaktadır.

\section{Sonuç ve Tartışma}

Araştırma sonuçları değerlendirildiğinde eğitim yöneticilerinin başkalarının duygularını değerlendirme dışındaki duygusal zekâ yeteneklerinde cinsiyet değişkenine göre anlamlı farklılaşma bulunmamaktadır. Bu bulgu benzer sonuçları içeren araştırma bulgularıyla örtüşmektedir (Özdemir ve Özdemir, 2007; Rahman, Ferdausy ve Uddin, 2012; Yaşlığlu ve diğerleri, 2013). Anlamlı farkın ortaya çıktığ1 başkalarının duygularını değerlendirme alt ölçeğinde ise bu farkın kadın eğitim yöneticileri lehine olduğu belirlenmiştir. Kadın eğitim yöneticilerin başkalarının duygularını değerlendirme yetenekleri erkek eğitim yöneticilerinden daha yüksektir. Duygusal zekâ ile Çakanel'in (2018) yapmış olduğu çalışmada bu çalışmada olduğu gibi cinsiyete göre duygusal zekâ yetenekleri açısından bir farklılık söz konusu olmazken sadece başkalarının duygularını değerlendirme boyutunda kadınların lehine anlamlı farklılık bulunmuştur. Kadın eğitim yöneticilerinin erkek eğitim yöneticilerine göre başkalarının duygularını değerlendirme alt boyutunda puan ortalamalarının daha yüksek olmasının sebebi olarak kadınların tarihsel süreç içerisinde erkeklere göre daha az güçlü olduklarından dolayı duygulara daha odaklı olmaları ve bu yüzden de bu yeteneklerini daha 
çok geliştirdikleri söylenebilir. Nitekim Mayer ve diğerleri (1999) de kadınların duygusal zekâlarının erkeklerden daha yüksek çıkmasını iki sebebe bağlamaktadır. Birincisi biyolojik olarak kadınların bu şekilde donatıldıkları, ikinci olarak da kadınların toplumda daha az güce sahip olduklarından dolayı duyguları daha dikkatli okumak zorunda olduklarıdır.

Eğitim yöneticilerinin sosyal farkındalık boyutu dışındaki sosyal zekâ yeteneklerinde cinsiyet değişkenine göre anlamlı farklılaşma bulunmamaktadır. Anlamlı farkın ortaya çıktığı sosyal farkındalık alt ölçeğinde ise bu farkın kadın eğitim yöneticileri lehine olduğu belirlenmiştir. Kadın eğitim yöneticilerin sosyal farkındalık yetenekleri erkek eğitim yöneticilerinden daha yüksektir. Bu bulgu Doğan ve diğerleri, (2009) ve Ülker'in (2016) yapmış oldukları araştırma bulguları ile örtüşmektedir. Sosyal Farkındalık alt boyutunda kadın eğitim yöneticilerinin erkek eğitim yöneticilerine göre puan ortalamalarının daha yüksek olmasının sebebi hem biyolojik olarak hem de tarihsel süreç içerisinde kadınların uyum sağlama ve tepkilerini kontrol etme yeteneklerinin erkeklere göre daha gelişmiş olduğu ile açıklanabilir. Çünkü sosyal farkındalık; Bireylere içinde bulundukları ortama uygun davranma yeteneği kazandırır. Doğru tepkiler vermesini ve geri bildirimde bulunmasını sağlar (Çakanel, 2018).

Eğitim yöneticilerinin liderlik stillerinde, serbestlik tanıyan liderlik dışındaki dönüşümcü liderlik ve sürdürümcü liderlik stillerinde cinsiyet değişkenine göre anlamlı farklılaşma bulunmaktadır. Dönüşümcü liderlik stilinde anlamlı farkın, kadın eğitim yöneticilerinin lehine olduğu belirlenmiştir. Sürdürümcü liderlik stilinde ise anlamlı farkın erkek eğitim yöneticilerin lehine olduğu tespit edilmiştir. Bu sonuca göre kadın eğitim yöneticilerinin erkek eğitim yöneticilerinden daha fazla dönüşümcü liderliği kullandığı, erkek eğitim yöneticilerinin ise kadın eğitim yöneticilerinden daha fazla sürdürümcü liderliği kullandığ1 ve serbestlik tanıyan liderlik stilinde cinsiyetin önemli bir değişken olmadığı söylenebilir. Ancak alanyazın incelendiğinde cinsiyet ile liderlik tarzları arasında bir ilişki olmadığını gösteren araştırmalar bulunmaktadır (Karataş, 2017; Monahan ve Shah, 2011; Joo, 2014).

Duygusal zekâ yeteneklerinden kendi duygularını değerlendirme, başkalarının duygularını değerlendirme ve duygularını kullanma puan ortalamalarının yaş değişkenine göre farklılaştığı bulunmuştur. Kendi duygularını değerlendirme alt boyutunda farkın 23-40 yaş arasında olan eğitim yöneticileri ve 41-50 yaş arasında olan eğitim yöneticileri ile 51 ve üzeri yaşta olan eğitim yöneticileri arasında olduğu belirlenmiştir. Buna göre eğitim yöneticilerinin yaşı arttıkça duygusal zekâ puanları azalmaktadır. Bu sonucu yöneticilere verilen eğitimin içeriği ile açıklayabiliriz. Duygusal zekâ kavramı 90'lı yılların başından itibaren popüler bir kavram olmuş ve eğitimde önemi etkili hale gelerek eğitim programlarının içeriğine alınmaya başlanmıştır (Bar-On, 1996; Elias ve diğerleri, 1999; Goleman, 1995, 1998; Saarni, 1997; Zins ve diğerleri, 1997). 51 ve üzeri yaşlarda olan eğitim yöneticilerinin duygusal zekaya önem veren bir eğitim sisteminden geçmemiş olması duygusal zekâ yeteneklerini daha genç olan eğitim yöneticilerine göre daha az geliştirdiklerini gösterebilir. Bu sonuç Özdenk'in (2015) yapmış olduğu çalışmasının bulgularıyla paralellik göstermektedir.

Ĕ̆itim yöneticilerinin sosyal farkındalık boyutu dışındaki sosyal zekâ yeteneklerinde yaş değişkenine göre anlamlı farklılaşma bulunmamaktadır. Anlamlı farkın ortaya çıktığı sosyal farkındalık alt ölçeğinde ise bu farkın 23-40 yaş arasında olan eğitim yöneticileri ile 41-50 yaş arasında olan eğitim yöneticileri ve 51 yaş ve üzerinde olan eğitim yöneticileri arasında olduğu belirlenmiştir. Jeloudar ve Yusunu'nun (2011) yapmış oldukları çalışmanın sonuçları bu bulguyu desteklemektedir.

Eğitim yöneticilerinin liderlik stillerinde, dönüşümcü liderlik dışındaki sürdürümcü liderlik ve serbestlik tanıyan liderlik stillerinde yaş değişkenine göre anlamlı farklılaşma bulunmaktadır. Sürdürümcü liderlik stilinde anlamlı farkın, 41-50 yaş arasında olan eğitim yöneticileri ve 51 ve üzeri yaşta olan eğitim yöneticileri ile 23-40 yaş arasında olan eğitim yöneticileri arasında olduğu belirlenmiştir. Serbestlik tanıyan liderlik stilinde anlamlı farkın 51 ve üzeri yaşta olan eğitim yöneticileri ile 41-50 yaş arasında olan eğitim yöneticileri ve 23-40 yaş arasında olan eğitim yöneticileri arasında olduğu belirlenmiştir. Buna göre yaş arttıkça eğitim yöneticilerinin sürdürümcü ve serbestlik tanıyan liderlik stillerini daha fazla kullandıkları söylenebilir. Ancak alanyazın incelendiğinde yaş ile liderlik tarzları arasında bir ilişki olmadığını gösteren araştırmalar bulunmaktadır (Guidry, 2007; Karataş, 2017; Monahan ve Shah, 2011; Joo, 2014). 
Eğitim yöneticilerinin duygusal zekâ yetenekleri dönüşümcü liderlik ve serbestlik tanıyan liderlik stillerini yordamaktadır. Dönüşümcü liderliğin önemli yordayıcıları başkalarının duygularını değerlendirme ve duyguları kullanma yetenekleridir. Dönüşümcü liderlik anlayışına göre lider, izleyicilerinin ihtiyaçlarını, inançlarını, değer yargılarını değiştiren kişidir (Koçel, 2007 aktaran Köksal, 2011). Bunu yaparken de çalışanların duygularını göz önüne alarak değerlendirip, duyguları doğru kullanarak değişime etki ettiği söylenebilir. Bu bulgu benzer sonuçları içeren araştırma bulgularıyla örtüşmektedir (Downey ve diğerleri, 2006; Gardner ve Stough 2002). Serbestlik tanıyan liderliğin önemli yordayıcıları kendi duygularını değerlendirme ve duyguları kullanma yetenekleridir. Serbestlik tanıyan liderlikte, lider birçok durumda kayıtsız davrandığından alınması gereken kararlar zamanında alınamaz. Lider çalışanlarını güdülemek ve ihtiyaçlarına cevap vermek için fazladan çaba harcamaz (Eğriboyun, 2015, akt. Zengin, 2018). Böyle bir liderin kendi duygularını değerlendirmede ve duyguları kullanma da zayıf olduğu söylenebilir. Bu bulgu ışı̆̆ında duygusal zekâsı düşük eğitim yöneticilerinin serbestlik tanıyan liderliği daha çok kullandığı tespit edilmiştir.

Eğitim yöneticilerinin sosyal zekâ yetenekleri dönüşümcü, sürdürümcü ve serbestlik tanıyan liderlik stillerini yordamaktadır. Dönüşümcü liderliğin önemli yordayıcıları, sosyal bilgi süreci, sosyal beceri ve sosyal farkındalık yetenekleridir. Dönüşümcü liderler; örgütte çalışan bireylerin enerjilerini, beklentilerini, taleplerini ve hedeflerini grubun amaçları doğrultusunda şekillendirerek ortak bir amaç, inanç ve eşgüdüm oluşturarak grubun yaşam kalitesini arttıran, bu sayede amaçların gerçekleşmesi adına aslında bir sinerji ortaya çıkarmayı başaranlardır (Akan ve Yalçın, 2015). Bu doğrultuda sağlıklı iletişim kurabilen, sözlü-sözsüz ifadeleri doğru anlayabilen, doğru tepkiler ve geri bildirimlerde bulunan liderlerin bunu gerçekleştirebileceği söylenebilir. Bu bulgu benzer sonuçları içeren araştırma bulgularıyla paralellik göstermektedir (Wessel ve diğerleri, 2008 ve Gilbert, 1994). Sürdürümcü liderliğin yordayıcısının sosyal farkındalık yeteneği olduğu saptanmıştır. Kontrole büyük önem veren sürdürümcü liderler astlarının psikolojik durumlarını önemsemeyerek programlanmış birer robot gibi davranmalarını isterler (Güney, 2009). Böyle liderlerin insan ilişkilerinde doğru tepkiler ve besleyici geri bildirimler vermelerini beklemenin pek doğru olmayacağ1 söylenebilir. Serbestlik tanıyan liderliğin yordayıcılarının sosyal bilgi süreci ve sosyal farkındalık yetenekleri olduğu belirlenmiştir. Bass ve Avolio (2000) sorunları sürekli erteleyen, karar vermekten kaçınan ve ihtiyaç duyulduğunda ortada olmayan lider davranışını serbestlik tanıyan lider olarak tanımlamaktadır. Bu tarz liderlerin astlarıyla iletişimlerinde sözlü-sözsüz ifadeleri doğru anlamadığı, doğru tepkiler ve geri bildirimler veremediği söylenebilir. Bu bulgular ışığında sosyal zekâsı düşük eğitim yöneticilerinin sürdürümcü ve serbestlik tanıyan liderliği daha çok kullandığı tespit edilmiştir.

Bu çalışma İstanbul ilinin belirli bir bölgesindeki okul müdürleri ile yürütülmüştür. Daha büyük gruplar ve farklı coğrafi bölgelerden katılımcılarla daha genelleyici araştırmalar yapılabilir. Araştırma bulgularımız nicel bir araştırma metoduna dayanmakta olup kullanılan ölçekler de katılımcıların öz değerlendirmeleri esas alınmıştır. Yine duygusal zekanın ve sosyal zekanın okul yöneticilerinde dönüşümcü ve sürdürümcü liderlik davranışlarının yordayıcısı olduğundan, okul yöneticisi yetiştiren kurumlarda duygusal ve sosyal zekâ düzeylerini arttırıcı etkinlikler yapılabilir, eğitim programları oluşturulurken bu iki değişkenin ağırlıklı olduğu programlar hazırlanabilir. Eğitim yöneticilerinin hem yönetsel hem eğitsel görevleri vardır. Dolayısıyla öğrenciler ile sürekli olarak iletişim içerisindedirler. Etkili liderlik davranışları sergilemeleri yetiştirecekleri öğrencilerin yeterliliği açısından da oldukça önemlidir. Bu anlamda eğitim yöneticilerinin duygusal ve sosyal zekâ yeteneklerinin geliştirilebilir birer olgu olarak düşünüldügünde duygusal ve sosyal zekâ yeteneklerini geliştirici hizmet içi eğitimlere yer verilmesi faydalı olabilir.

\section{Yazar(lar)1n Beyanı}

Araştırmacıların katkı oranı beyanı: Tüm yazarlar eşit oranda çalışmaya katkıda bulunmuşlardır.

Etik Kurul Kararı: İstanbul Medeniyet Üniversitesi'nin Ĕ̆itim Bilimleri Bölümü Etik Kurulu 07/06/2021 tarih ve 2021/06-29 sayll kararı

Çatışma beyanı: Araştırmada yazarların kendi içinde diğer kişi/kurum/kuruluşlarla herhangi bir çıkar çatışması söz konusu değildir. 
Destek ve teşekkür: Bu araştırmanın yürütülmesi sürecinde herhangi bir destek alınmamıştır.

\section{Kaynaklar}

Akan D. \&Yalçın S. (2015). Okul yöneticilerinin dönüşümcü liderlik stili ile öğretmenlerin örgütsel bağlllıkları arasındaki ilişkinin incelenmesi. Ĕ̆itim ve İnsani Bilimler Dergisi: Teori ve Uygulama, 6(11), 123-150.

Akdoğan, E. (2002). Öğretim elemanlarının algıladıkları liderlik stilleri ile iş doyum düzeyleri arasındaki ilişki. [Yayınlanmamış yüksek lisans tezi.] Marmara Üniversitesi.

Albert, K. (2006). Sosyal zekâ başarının yeni bilimi. (S. Göktan, Çev.). Timaş Yayınları.

Balcı, A. (2010). Açıklamalı eğitim yönetimi terimleri sözlüğü. Pegem Yayıncılık.

Baloğlu, N., Karadağ, E., \& Gavuz, Ş. (2009). Okul müdürlerinin çok faktörlü liderlik stillerinin yetki devrine etkisi: Bir doğrusal ve yapısal eşitlik modelleme çalışması. Uludă̆ Üniversitesi Eğitim Fakültesi Dergisi, 22(2), 457-479.

Bar-On, R. (1996). The era of the EQ: Defining and assessing emotional intelligence. Poster session presented at the annual convention of the American Psychological Association, Toronto, Canada.

Bass, B. M. (1998). Transformational leadership: Industrial, military, and educational impact. Lawrence Erlbaum Associates.

Bass, B. M., \& Avolio, B. J. (2000). MLQ: Multifactor leadership questionnaire. Mind Garden.

Björkqvist, K., Österman, K., \& Kaukiainen, A. (2000). Social intelligence, empathy, aggression? Aggression and violent behavior, 5(2), 191-200.

Bollen, K.A. (1989). A new incremental fit index for general structural equation models. Sociological Methods and Research, 17(3), 303-316.

Boyatzis, R. E. (2009). Competencies as a behavioral approach to emotional intelligence. Journal of Management Development, 28(9), 749-770.

Browne, M. W., \& Cudeck, R. (1993). Alternative ways of assessing model fit. Sage Focus Editions, 154, 136-136.

Burns, J. M. (1978). Leadership. Harper \& Row.

Connelly, S., \& Ruark, G. (2010). Leadership style and activating potential moderators of the relationships among leader emotional displays and outcomes. The Leadership Quarterly, 21(5), 745-764.

Çaka, U., \& Arbak, Y. (2003). Dönüşümcü liderlik duygusal zekâ gerektirir mi? Yöneticiler üzerinde örnek bir çalışma. Dokuz Eylül Üniversitesi İktisadi İdari Bilimler Fakültesi Dergisi, 18(2), 83-98.

Çakanel, Z. (2018). Duygusal zekâ, sosyal zekâ ve sosyal girişimcilik arasındaki ilişkinin incelenmesi. [Yayınlanmamış Yüksek Lisans Tezi]. Pamukkale Üniversitesi.

Deniz, M. (2012). Duygusal zekâ boyutları ile liderlik uygulamaları arasındaki ilişki: Sağlık sektörü yöneticileri üzerine bir araştırma. e-Journal of New World Sciences Academy NWSA, 7(2), 45-66.

Doğan, T. \& Çetin, B. (2009). Tromso sosyal zekâ ölçeği türkçe formunun faktör yapısı, geçerlik ve güvenirlik çalışması. Kuram ve Uygulamada Eğitim Bilimleri, 9(2), 691-720.

Doğan, T., Totan, T., \& Sapmaz, F. (2009). Üniversite öğrencilerinde benlik saygısı ve sosyal zekâ. Sakarya Üniversitesi Ĕ̆itim Fakültesi Dergisi, 17, 235-247.

Downey, L.A., Papageorgiou, V., \& Stough, C. (2006) Examining the relationship between leadership, emotional intelligence and intuition in senior female managers. Leadership \& Organization Development Journal, 27(4), 250-264.

Downton, J. V. (1973). Rebel leadership: Commitment and charisma in a revolutionary process. Free 
Okul Yöneticilerinin Duygusal ve Sosyal Zekâları ile Liderlik Stilleri Arasındaki...

Duckett, H., \& Macfarlane, E. (2003). Emotional intelligence and transformational leadership in retailing. Leadership \& Organization Development Journal, 24(5/6), 309-317.

Elias, M., Tobias, S. \& Friedlander, B. (1999). Emotionally intelligent parenting. Harmony Boks.

Erkuş, A. \& Günlü, E. (2008). Duygusal zekanın dönüşümcü liderlik üzerine etkileri. Işsletme Fakültesi Dergisi, 9(2), 187-209.

Gardner, L., \& Stough, C. (2002). Examining the relationship between leadership and emotional intelligence in senior level managers. Leadership \& Organization Development Journal, 23(2), 68-78.

Genc, V. \& Gulertekin Genc, S. (2018). Can hotel managers with social intelligence affect the emotions of employees? Cogent Business \& Management, 5(1), 1-16.

George, D., \& Mallery, M. (2010). SPSS for windows step by step: A simple guide and reference. Pearson.

Gilbert, J.A. (1994). Leadership, social intelligence, and perceptions of environmental opportunities: A comparison across levels of leadership. [Unpublished doctoral thesis]. George Mason University.

Goleman, D. (1995). Emotional intelligence. Bantam.

Goleman, D. (1998). Working with emotional intelligence. Bantam.

Goleman, D. (2002). Lideri lider yapan nedir? (N. Elhüseyni, Çev.). MESS Yayınları.

Goleman, D. (2014). Sosyal zekâ. Varlık Yayınları.

Guidry, T.C. (2007). Women deans' perceptions of their leadership styles: a study based on Bolman and Deal's four frame theory. [Unpublished doctoral thesis]. East Carolina University.

Güney, F. (2009). Okul yöneticilerinin duygusal zekâ düzeyleri ile çatısma yönetimi stratejileri arasındaki ilişki. [Yayınlanmamış yüksek lisans tezi]. Maltepe Üniversitesi.

Gürbüz, S. \& Yüksel, M. (2008). Çalışma ortamında duygusal zekâ: İş performansı, iş tatmini, örgütsel vatandaşlık davranışı ve bazı demografik özelliklerle ilişkisi. Doğuş Üniversitesi Dergisi, 9 (2), 174-190.

Hayashi, A., \& Ewert, A. (2006). Outdoor leaders' emotional intelligence and transformational leadership. Journal of Experiential Education, 328(3), 222-242.

Hırlak, B., Taşlıyan, M., Fidan, E., \& Gül, H. (2017). Duygusal zekânın iş performansı ve bazı demografik özellikler ile ilişkisi: Kahramanmaraş'ta üretim sektöründe bir uygulama. Kesit Akademi Dergisi, 3(9), 108-130.

Jeloudar, Y.S., \& Yusunu, A.S. (2011). Exploring the relationship between teachers' social intelligence and classroom discipline strategies. International Journal of Psychological Studies, 3(2), 149-155.

Joo, M.T.H. (2014). The influence of multi-frame leadership style on organizational climate in a private university in Malaysia: A case study. [Unpublished doctoral thesis]. The University of Malaya.

Kanbur, A. (2015). İ̧̧-aile/aile-iş çatışması ile mücadele etmenin bir yolu olarak sosyal zekanın keşfedilmesi üzerine bir araştırma. İşletme Araştırma Dergisi, 7(1), 145-167.

Kapıkıran, N. A. (2004). Okul öncesi öğretmenlerde tükenmişliğin bazı değişkenler açısından incelenmesi. Ĕ̆itim Araştırmaları, 4(13), 73-78.

Karadavut, Y. \& Çetin, Ş. (2018). Duygusal zekânın liderlik üzerine etkisi: Okul yöneticileri üzerine bir araştırma. Kalem Ĕ̆itim ve İnsan Bilimleri Dergisi, 8(2), 359-386

Karasar, N. (2002). Bilimsel araştırma yöntemi. Nobel.

Karataş, E.Ö. (2017). Beden eğitimi ve spor yüksekokulu öğrencilerinin liderlik yönelimleri ve öz güven davranışlarının incelenmesi. [Yayınlanmamış yüksek lisans tezi]. İnönü Üniversitesi 
Kline, R. B. (2011). Principles and practice of structural equation modelling. The Guilford Press.

Kobe, L. M., Reiter-Palmon, R., \& Rickers, J. D. (2001). Self-reported leadership experiences in relation to inventoried social and emotional intelligence. Current Psychology, 20(2), 154-163.

Köksal, O. (2011). Bir kültürel liderlik paradoksu: Paternalizm. Mustafa Kemal Üniversitesi Sosyal Bilimler Enstitüsü Dergisi, 8(15), 101-122.

Kutlualp Göktaş, H. \& Erol, S. (2017). Yöneticilerde duygusal zekânın etik liderlik davranışı üzerindeki etkisi. Uluslararası Sosyal Araştırmalar Dergisi, 10(52), 1045-1057.

Lathesh, K. R., \& Avadhani, V. D. (2018). A study on social intelligence and its impact on employee performance of insurance sectors in Mysuru city. International Journal of Mechanical Engineering and Technology, 9(1), 530-537.

Leithwood, K. A. (1992). The move toward transformational leadership. Educational Leadership, 49(5), 8-12.

Mandell, B., \& Pherwani, S. (2003) Relationship between emotional intelligence and transformational leadership style. Journal of Business and Psychology, 17(2), 387-404.

Mayer, J. D., Caruso, D. R., \& Salovey, P. (1999). Emotional intelligence meets traditional standards for an intelligence. Intelligence, 27(4), 267-298.

MEB, (2021). Millî eğitim bakanlı̆̆ına bağh eğitim kurumlarna yönetici seçme ve görevlendirme yönetmeliği. T.C. Resmî Gazete, 05 Şubat 2021, sayı: 31386.

Mills, L. B. (2009). A meta-analysis of the relationship between emotional intelligence and effective leadership. Journal of Curriculum and Instruction, 3(2), 22-38.

Monahan, M., \& Shah, A.J. (2011). Having the right tools: the leadership frames of university presidents. The Coastal Business Journal, 10(1), 14-30.

Mumcuoğlu, Ö. (2002). BarOn duygusal zekâ testi'nin türkçe dilsel eşdeğerlik, güvenirlik ve geçerlilik çalışması. [Yayınlanmış Yüksek Lisans Tezi]. Marmara Üniversitesi.

Özcan, M. (2018). Öğretmen adaylarının sosyal zeka düzeylerinin incelenmesi. Eğitimde Yeni Yaklaşımlar Dergisi, 1(1), 42-51.

Özdemir, Y. \& Özdemir, A. (2007). Duygusal zekâ ve çatışma yönetimi stratejileri arasındaki ilişkilerin incelenmesi: Üniversitede çalışan akademik ve idari personel üzerine uygulama. Selçuk Üniversitesi Sosyal Bilimler Enstitüsü Dergisi, 18, 393-410

Özdenk, S. (2015). Bireysel ve takım sporuyla uğraşan sporcular ile spor yapmayan bireylerin duygusal zekâ ve liderlik özelliklerinin incelenmesi. [Yayınlanmamış doktora tezi]. Gazi Üniversitesi.

Palmer, B., Walls, M., Burgess, Z., \& Stough, C. (2001). Emotional intelligence and effective leadership. Leadership \& Organization Development Journal, 22(1), 5-10.

Rahman, S., Ferdausy, S., \& Uddin, A. (2012). Exploring the relationships between emotional intelligence, leadership styles, and gender: An empirical study. SIU Journal of Management, 2(2), 27-57.

Saarni, C. (1997). Emotional competence and self-regulation in children. P. Salovey, D. Sluyter (Eds), Emotional development and emotional intelligence. içinde (ss. 35-66). Basic Boks.

Salovey, P. \& Mayer, J. (1990). Emotional intelligence. Imagination, Cognition and Personality, 9 (3), 185-211.

Sayeed, O., \& Shanker, M. (2009). Emotionally intelligent managers \& transformational leadership styles. Indian Journal of Industrial Relations, 44(4), 593-610.

Selçuk, Z., Kayılı, H. \& Okut, L. (2002). Çoklu zekâ uygulamaları. Nobel. 
Sosik, J.J., \& Megerian, L.E. (1999) Understanding leader emotional intelligence and performance. Group $\mathcal{E}$ Organization Management, 24(3), 367-390.

Şahin, S., \& Şahin Yüksel, F. (2017). Okul yöneticilerinin ve öğretmenlerin çatışma yönetimi stillerinin sosyal zekâ ve bazı kişisel değişkenlere göre incelenmesi. Kalem Eğitim ve İnsan Bilimleri Dergisi, $7(2)$, 391-418.

Şenturan, Ş. (2014). Örgütsel davranış. Beta Yayınları.

Tanrıöğen, A. (1997). Temel eğitim öğretmenlerinin yirmi birinci yüzyılın öğretmeninde bulunması gereken niteliklere ilişkin beklentileri, Uluslararası Öğretmen Yetiştirme Sempozyumu-1, Çanakkale Onsekiz Mart Üniversitesi, 27-28 Kasım 1997.

Tichy, N. M., \& Devanna, M. A. (1986). The transformational leadership. Wiley.

Türker, Y. (2019). Okul müdürlerinin liderlik tarzlarının öğretmenlerin sosyal ve duygusal zekalarına etkisi. [Yayınlanmamış doktora tezi]. Pamukkale Üniversitesi.

Ülker, Ç. (2016). Meslek yüksekokulu öğrencilerinin sosyal zekâ ve iletişim becerilerinin farklı değişkenler açısından incelenmesi. [Yayınlanmamış yüksek lisans tezi]. Nişantaşı Üniversitesi.

Weisinger, H. (1998). İş yaşamında duygusal zekâ. MNS Yayıncılık.

Wessel, J., Larin, H., Benson, G., Brown, B., Ploeg, J., Williams, R., \& Martin, L. (2008). Emotional- social intelligence in health science students and its relation to leadership, caring and moral judgment. The Internet Journal of Allied Health Science and Practise, 6(1), 1-9.

Wong, C. S., \& Law, K. S. (2002). The effects of leader and follower emotional intelligence on performance and attitude: An exploratory study. The Leadership Quarterly, 13(3), 243-274.

Yaşlığlu, M. M., Pekdemir, I., \& Toplu, D. (2013). Duygusal zeka ve çatışma yönetimin yöntemleri arasındaki ilişki ve bu ilişkide lider üye etkileşiminin rolü. Yönetim Bilimleri Dergisi, 11(22), 191-220.

Yeşilyaprak, B. (2001). Duygusal zekâ ve eğitim açısından doğurguları. Kuram ve Uygulamada Eğitim Yönetimi, 25, 139-146.

Zengin, A.A. (2018). Alg̨lanan liderlik stilinin iş yaşam kalitesi üzerine etkisi: x ve y kuşakları arası karşılaştırma. [Yayınlanmamış yüksek lisans tezi]. Nişantaşı Üniversitesi.

Zins, J., Travis, L. ve Freppon, P. (1997). Linking research and educational programming to promote social and emotional learning. P. Salovey, D. Sluyter (Eds), Emotional development and emotional intelligence. içinde (ss. 257-274). Basic Boks. 


\section{EXTENDED ABSTRACT}

\section{Introduction}

When the literature is examined, it is seen that there are many studies examining the relationship between transformational leadership and emotional intelligence (Çaka \& Arbak, 2003; Ducket \& Macfarlane, 2003; Gardner \& Stough, 2002; Erkuş \& Günlü, 2008; Sosik \& Megerian, 1999; Downey, Papageorgiou \& Stough) 2006), however, there are no studies examining the relationship between transformational leadership and social intelligence among the ones reached out. Similarly, no study has been found that examines transactional leadership and laissez-faire leadership, emotional intelligence skills and social intelligence skills. In this respect, it is considered to be highly important to examine the relationship between emotional intelligence skills and social intelligence skills of school principals and their leadership styles in terms of contributing to the relevant literature. At the same time, the studies carried out in this aspect are thought to make school principals aware of the qualifications that affect the fulfillment of their professional responsibilities, and thus to contribute to the success of the schools. Therefore, the aim of this study is to determine whether the emotional intelligence and social intelligence skills of school principals differ significantly in terms of gender and age variables, and whether the emotional intelligence and social intelligence skills of school principals significantly predict their leadership styles.

\section{Method}

Correlational survey model was used in this research that was prepared to examine the relationship between the emotional intelligence and social intelligence skills of school principals and their leadership styles. The population of the research consists of all 397 school principals working in the state schools in Avclar, Beyoğlu, Çatalca, Esenyurt and Güngören districts of Istanbul in the 2019-2020 academic year. The study sample consists of a total of 277 school principals, 67 women and 210 men, who work in the same districts and were determined with the simple random sampling method from the population. The Wong \& Law Emotional Intelligence Scale (WLEIS), the Tromso Social Intelligence Scale and the Multi-Factor Leadership Scale were used to collect the data of the study. Independent t-test, one-way analysis of variance, Tukey test and multivariate linear regression analysis were used in the statistical analysis of the data.

\section{Results}

When the findings were evaluated, it was seen that there was no significant difference in terms of the gender variable in the emotional intelligence skills of the school principals except for evaluating the emotions of others and in the social intelligence skills except for the social awareness dimension. A significant difference was observed in the transformational leadership and transactional leadership styles of the school principals in terms of the gender variable.

It was found that the mean scores of emotional intelligence skills such as evaluating one's own emotions, evaluating the emotions of others and using their emotions differ in terms of the age variable. There was no significant difference in the school principals' social intelligence skills except for the social awareness dimension in terms of the age variable. A significant difference was observed in the transactional leadership and laissez-faire leadership styles of the school principals in terms of the age variable.

It was seen that emotional intelligence skills of the school principals predicted their transformational leadership and laissez-faire leadership styles. In addition, social intelligence skills of the school principals predicted their transformational, transactional and laissez-faire leadership styles.

\section{Conclusion}

The most important predictors of the transformational leadership are the skills to evaluate and use emotions of others. According to the transformational leadership approach, a leader is a person who changes the needs, beliefs and value judgments of his followers (Koçel, 2007; cited in Köksal, 2011). While doing this, the leader can be considered to affect the change by evaluating the emotions of the employees and using the emotions correctly. The important predictors of the laissez-faire leadership are their ability to evaluate their 
own emotions and use them. In laissez-faire leadership, the decisions that are necessary to be taken cannot be made in a timely manner because the leader acts indifferently in many situations. Leaders do not make extra efforts to motivate their employees and respond to their needs (Eğriboyun, 2015, cited in Zengin, 2018). It can be said that such a leader is weak in evaluating his own emotions and using emotions. In the light of this finding, it can be thought that school principals with low emotional intelligence use laissez-faire leadership more.

The most important predictors of the transformational leadership from social intelligence skills are social information process, social skills and social awareness skills. Transformational leaders are those who shape the energies, expectations, demands and goals of the individuals working in the organization in line with the goals of the group and increase the quality of life of the group by creating a common purpose, belief and coordination, and thus succeed in creating a synergy to realize the goals (Akan \& Yalçın, 2015). In this direction, it can be said that leaders who can communicate well, understand verbal and non-verbal expressions correctly, and give correct reactions and feedback can achieve this. It has been determined that the predictor of the transactional leadership is social awareness skills. Transactional leaders, who attach great importance to control, want their subordinates to behave like programmed robots by ignoring their psychological states (Güney, 2009). It can be said that it would not be right to expect such leaders to provide correct responses and nurture feedback in human relations. It has been determined that the predictors of laissez-faire leadership are social information process and social awareness skills. Bass and Avolio (2000) define the leader who postpones the problems, avoids making decisions, and disappears when needed as the laissez-faire leader. It can be said that such leaders do not understand verbal and nonverbal expressions correctly in their communication with their subordinates, and cannot provide correct responses and feedback. In the light of these findings, it can be thought that the school principals with low social intelligence use the transactional and laissez-faire leadership more.

This study was carried out with the school principals in a certain region of Istanbul. Similar studies can be conducted on larger samples in order to increase the generalizability of the research. Our research findings are based on a quantitative research method and the scales used are based on the self-evaluations of the participants. Since emotional intelligence and social intelligence are the predictors of the transformational and transactional leadership behaviors of school principals, activities to increase emotional and social intelligence levels can be carried out in institutions that train school principals, and programs in which these two variables are predominant can be prepared while designing training programs. School principals have both administrative and educational duties. Therefore, they are in constant communication with the students. Having effective leadership behaviors is also important in terms of the competence of the students they will train. In this sense, considering the emotional and social intelligence skills of school principals as a phenomenon that can be developed, it may be beneficial to include in-service trainings that improve their emotional and social intelligence skills. 